\title{
Angiogenic activity of latex from Euphorbia tirucalli Linnaeus 1753 (Plantae, Euphorbiaceae)
}

\author{
Bessa, G. ${ }^{a}$, Melo-Reis, PR. ${ }^{b *}$, Araújo, LA. ${ }^{a}$, Mrué, F., \\ Freitas, GB. ${ }^{a}$, Brandão, ML. ${ }^{c}$ and Silva Júnior, NJ. ${ }^{a}$ \\ aPró-Reitoria de Pós-graduação e Pesquisa, Pontifícia Universidade Católica de Goiás - PUC-GO, \\ Campus I, Rua 232, 128, $3^{\circ}$ andar, Área V, CEP 74605-140, Goiânia, GO, Brazil \\ baboratório de Estudos Experimentais e Biotecnológicos - LEB, Programa de Pós-graduação em Ciências Ambientais e \\ Saúde, Departamento de Biomedicina e Farmácia, Pontifícia Universidade Católica de Goiás - PUC-GO, Campus I, \\ Rua, 232, 128, $3^{\circ}$ andar, sala 6, Área V, CEP 74605-140, Goiânia, GO, Brazil \\ 'Departamento de Medicina, Pontifícia Universidade Católica de Goiás - PUC-GO, Campus I, \\ Avenida Universitária, 1440, Setor Universitário, Área IV, Bloco I, CEP 74605-010, Goiânia, GO, Brazil \\ *e-mail: melo_reis@yahoo.com.br
}

Received: January 17, 2014 - Accepted: March 10, 2014 - Distributed: August 31, 2015

(With 3 figures)

\begin{abstract}
To assess the pro-angiogenic activity of Euphorbia tirucalli, commonly known as "avelós" plant, we performed a series of tests by applying an aqueous E. tirucalli latex solution $(10 \mathrm{mg} / \mathrm{mL})$ to the chorioallantoic membranes (CAMs) of 80 fertilized chicken eggs incubated in a temperature- and humidity-controlled automatic incubator. The results indicated that the aqueous latex solution increased vascular network formation compared to that with the negative control $(p<0.05)$ and the inhibitor control $(p<0.05)$. This suggests that under the experimental conditions tested, the aqueous latex solution induced an inflammatory response leading to neoangiogenesis.
\end{abstract}

Keywords: angiogenesis, chorioallantoic membrane, Euphorbia tirucalli.

\section{Atividade angiogênica do látex da Euphorbia tirucalli Linnaeus 1753 (Plantae, Euphorbiaceae)}

\begin{abstract}
Resumo
Com o objetivo de analisar a atividade angiogênica apresentada pela Euphorbia tirucalli, popularmente conhecida comumente como "avelós", foram realizados ensaios utilizando solução aquosa de látex na concentração de $10 \mathrm{mg} / \mathrm{ml}$, aplicada em membrana corioalantóide (MCA) de 80 ovos férteis de galinha, incubado em estufa automática com temperatura e umidade controladas. Os resultados apontaram que a ação da solução aquosa provocou aumento da percentagem da rede vascular formada em relação aos controles negativo $(p<0,05)$ e inibidor $(p<0,05)$, indicando que nas condições deste experimento, foi responsável pela ativação da resposta inflamatória e crescimento de novos vasos sanguíneos.
\end{abstract}

Palavras-chave: angiogênese, membrana corioalantóide, Euphorbia tirucalli.

\section{Introduction}

Angiogenesis is defined as the formation of new blood vessels from pre-existing capillary vessels, involving a series of coordinated events: proliferation of endothelial cells, migration of cells to distal points, cell realignment, vessel formation, and production of a new basement membrane (Folkman, 1976; Folkman and Ingber, 1992). It occurs in physiologic processes such as menstruation, ovulation, and wound healing. In the heart in particular, angiogenesis promotes vascular ramification of coronary vessels, increase in blood flow, and cardiac contractility. Angiogenesis also occurs in pathological processes such as chronic arthropathy, psoriasis, diabetic retinopathy, tumoral growth, and metastasis dissemination (González et al., 2000; Safatle et al., 2002; Folkman, 1976, 2004).

To date, diverse studies have been conducted with the aim of finding substances that can induce angiogenesis, since the possibilities of clinical application of these substances in myocardial vascularity and the central nervous system are extensive, after injury or ischemia, partial replacement of large arteries, and even in wound healing (Krupinski et al., 2003; Slevin et al., 2005). 
Medicinal plants and substances extracted from them have been used for thousands of years, fostering the prevention and treatment of disorders and dysfunctions in humans (Farnsworth et al., 1985; Ortêncio, 1997). Several plant species have shown biological activity that induces angiogenesis in vivo, namely Ginkgo biloba, Aloe vera, Angelica sinensis, Dalbergia odorifera, Epimedium sagittatum, Patrinia villosa, Trichosanthes kirilowii, Hevea brasiliensis, and Synadenium umbellatum (Juárez et al., 2000; Choi et al., 2002; Wang et al., 2004; Melo-Reis et al., 2010).

Euphorbia tirucalli Linnaeus 1753, of the family Euphorbiaceae, originally from Africa and introduced in Brazil, is commonly known as "avelós," and produces a type of latex that has been used in various ways in the treatment of diseases (Gurib-Fakim, 2006). Generally, latex is indicated for both prevention and treatment of malignant neoplasias (leukemia, skin cancer, and digestive tract cancer), and is also used as an immunomodulator, a healing agent, and in diabetes treatment (Ortêncio, 1997). Some studies performed using other species from the genus support the antitumor and angiogenic activity observed (Kupchan et al., 1976; Schroeder et al., 1980; Hubert and De-Thé, 1982; Yan et al., 2008).

Since popular use of medicinal plants provides evidence of biological activity, proper scientific research using adequate experimental models is necessary to validate the therapeutic use of these plants, or even to contribute to the formulation of a new drug (Heinrich and Gibbons, 2001).

In the present study, we aimed to assess the angiogenic activity of E. tirucalli latex by using the chicken embryo chorioallantoic membrane assay.

\section{Material and Methods}

\subsection{Latex extraction from E. tirucalli}

Latex from E. tirucalli was collected in the Laboratory of Experimental and Biotechnological Studies of the Master in Environmental and Health Sciences of the Pontifical Catholic University of Goiás (LEB/MCAS - PUC Goiás) (-1640'32.79”, - 49 14 '38.58”), identified by Dr. J. A. Rizzo from the Institute of Biological Sciences of the Federal University of Goiás (ICB - UFG), and deposited at the UFG Herbarium (exsiccate number, 47797). Latex was extracted by excision of the trunk of a specimen sample and was collected with a semi-automatic pipette. The latex was immediately weighed and transferred to a sterile glass container with distilled water. The initial amount was $0.1 \mathrm{~mL}$ of pure latex, corresponding to $100 \mathrm{mg}$. The sample was diluted in $9.9 \mathrm{~mL}$ distilled water to a final concentration of $10 \mathrm{mg} / \mathrm{mL}$, which was consistent with the concentration used in the pilot study for toxicological evaluation. The prepared material was stored at $4{ }^{\circ} \mathrm{C}$ for a maximum of 30 days (Mendonça, 2004; Mrué, 1997).

\subsection{Evaluation of pro-angiogenic activity using the chorioallantoic membrane assay}

\subsubsection{Fertilized chicken eggs}

We used 80 fertilized eggs obtained from Rhoss breed chicken (Gallus domesticus) from the Department of Animal Science of the Pontifical Catholic University of Goiás.

\subsubsection{Drugs and Reagents}

The following drugs and reagents were used in this study: sterile distilled water (Halex Istar Indústria Farmacêutica), dexamethasone (4 mg/mL, Aché Laboratórios Farmacêuticos; batch number, 2668), latex biomembrane (Biocure, Pele Nova Biotecnologia; batch number, 04080100), formaldehyde 37\% (Rioquímica Ltda; batch number, 0402296), paraffin (Petrobrás), hematoxylin-eosin (HE) staining kit (Doles reagentes).

\subsubsection{Experimental design}

Angiogenic activity was tested using the chorioallantoic membrane (CAM) assay. Briefly, fertilized chicken eggs were incubated at $38{ }^{\circ} \mathrm{C}$ and $65 \%$ humidity in an automatic incubator and moved laterally every $15 \mathrm{~min}$ for the first 5 days of incubation. In this assay, the first day of incubation is considered to be the start of embryonic development. At the end of the incubation period, a circular hole (1.0 cm in diameter) was made using a micro-drill in the blunt end of the eggs, the region that contains the air sac. Then, the eggshell in that area was removed to expose the vascularized CAM. The circular hole was sealed with transparent tape and the eggs were further incubated without periodic movement with the holes turned upwards (Figure 1a).

After 13 days of incubation, filter paper discs $(0.5 \mathrm{~cm}$ in diameter) impregnated with $3 \mu \mathrm{L}$ diluted E. tirucalli latex solution (test solution), sterile distilled water (negative control), 1\% dexamethasone (inhibitor control), or Biocure Biomembrane (inducer control, having the same diameter as that of the filter paper discs) were directly deposited over the membrane in 20 eggs per group, carefully to prevent rupture or death of the embryo (Figure 1b). The eggs were incubated until day 16, after which they were removed from the incubator and the CAM was fixed in $10 \%$ paraformaldehyde solution for $10 \mathrm{~min}$ (Staton et al.,2004).

\subsubsection{Image acquisition}

A digital camera (Sony Cyber Shot 6.0 megapixel) coupled to a light microscope was used for CAM imaging. In this system, the selected pixels are proportional to the degree of CAM vascularization, with a $640 \times 480$ pixel resolution and 24-bit RGB, according to the protocol established by Mendonça (2004). The images of newly formed CAM vascular networks were processed and quantified with the Gimp for Windows program (version 2.0.5) to better visualize the blood vessels. Image analysis was performed with Image J (version 1.28), which enables the separation of intensity degrees over intervals, and 


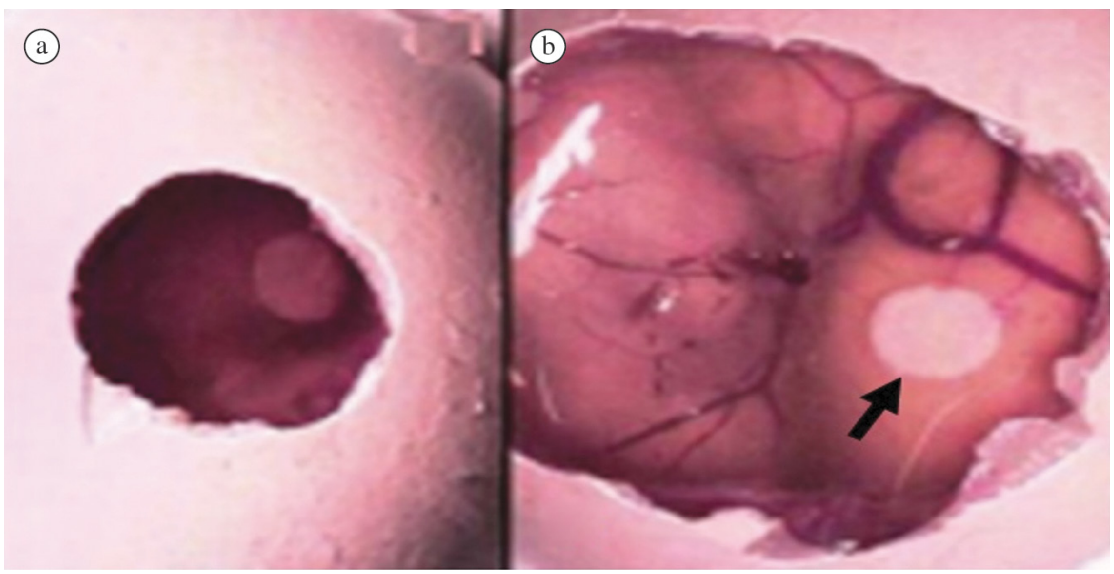

Figure 1. (a) Details of the circular hole with a $1.0 \mathrm{~cm}$ diameter in the eggshell. (b) Vascular network of the chorioallantoic membranes (CAM) at day 13 of development. The arrow indicates the filter paper discs impregnated with test solution or controls. The filter paper discs were placed in the proximity of a CAM high caliber blood vessel.

thus allows the isolation and quantification of pixels corresponding to blood vessels.

\subsubsection{Histological analysis}

The CAMs and their newly formed vascular networks were fixed in $10 \%$ paraformaldehyde solution and later embedded in paraffin. Each paraffin block was sectioned with a Spencer micrometer at a thickness of $5 \mu \mathrm{m}$. Next, the sections were stained with HE for light microscopy analysis. Images were acquired with a digital camera coupled to the microscope using a Pinnacle Studio AV/DV Deluxe capture board.

\subsubsection{Statistical analysis}

The angiogenic activity of E. tirucalli latex was analyzed by comparing the relative CAM areas between the different treatment groups and controls. The differences between independent samples were compared with the Kruskal-Wallis non-parametric test followed by the Dunn method for group comparisons. The analyses were performed with the BioEstat program (version 5.0 for Windows) and $p$ values less than $0.05(p<0.05)$ were considered statistically significant (Ayres et al., 2007).

\section{Results}

The results obtained from the newly formed vascular network were analyzed using two different methods. In the first method, we calculated the percentage of area and compared the vascular network of the controls and test. In the second, we conducted a histological analysis of the newly formed vascular network.

Compared to the negative control $(p<0.05)$ and the inhibitor control $(p<0.05)$ groups, the groups treated with the E. tirucalli latex aqueous solution showed increased neoangiogenesis. The mean area and standard deviation of the CAM vascular network in the E. tirucalli latex test group and negative control group were $46.3 \pm 3.8$ and $31.8 \pm 3.0$, respectively. The average CAM vascular network area in the inducer control group $(51.3 \pm 3.9)$ was not significantly different from that in the E. tirucalli latex test group $(p>0.05)$. However, a significant difference $(p<0.05)$ was observed between the inducer control and the negative control groups. The E. tirucalli latex aqueous solution and the biomembrane (Biocure) significantly increased vascularization $(p<0.05)$. The percentages of CAM vascularization in the different sample groups are shown in Table 1. In addition, CAM vascularization in the inhibitor control group $(11.6 \pm 1.9)$ was significantly different from that in the negative control group $(p<0.05)$.

Digital images of the vascular network in the different controls and those of the vascular network in the test solution-treated group (treated with negative and inhibitor controls), showed a larger newly formed vascular network in the CAMs treated with latex (Figure 2).

The results of the histological analysis of the different controls and of the group treated with the plant latex are in agreement with the findings observed on the digital images. A marked inhibition in blood vessel formation was observed in the inhibitor control (dexamethasone) group, because these samples have low levels of vascularization and disorganized endothelial cells (Figure $3 \mathrm{a}$ and $\mathrm{b}$ ). The positive control group (Figure 3c and d) and the E. tirucalli latex group (Figure 3e and f) showed a considerable increase in neoangiogenesis with a rich and organized vascular network as well as inflammatory cell infiltration.

\section{Discussion}

Medicinal plants are commonly used for therapeutic purposes in traditional medicine, and a variety of plants with potential pharmaceutical properties that are found in Brazil contribute to an increased consumption of phytotherapeutic products (Gurib-Fakim, 2006; Castro et al., 2004).

Plants belonging to the Euphorbiaceae family, in particular the Euphorbia genus, have shown different biological activities, including angiogenic activity, in different experimental models (Zhang et al., 2008; 


\begin{tabular}{ccccc}
\hline $\begin{array}{c}\text { Sample } \\
\text { number }\end{array}$ & $\begin{array}{c}\text { Inducer Control } \\
\text { (Biocure) }\end{array}$ & $\begin{array}{c}\text { Negative Control } \\
\left(\mathbf{H}_{2} \mathbf{O}\right)\end{array}$ & $\begin{array}{c}\text { Inhibitor Control } \\
\text { (Dexamethasone) }\end{array}$ & $\begin{array}{c}\text { Latex } \\
\boldsymbol{E} \text {. tirucalli }\end{array}$ \\
\hline 1 & 51.2 & 30.1 & 10.1 & 47.3 \\
2 & 48.7 & 34.6 & 15.3 & 45.2 \\
3 & 56.3 & 33.6 & 14.8 & 48.6 \\
4 & 48.4 & 38.5 & 15.8 & 48.5 \\
5 & 52.9 & 28.5 & 12.4 & 51.7 \\
6 & 53.7 & 35.7 & 11.9 & 48.8 \\
7 & 44.9 & 28.7 & 10.8 & 43.9 \\
8 & 48.4 & 26.5 & 9.5 & 44.1 \\
9 & 53.7 & 29.9 & 10.5 & 51.7 \\
10 & 55.2 & 31.3 & 12.9 & 50.9 \\
11 & 51.7 & 31.2 & 9.2 & 40.2 \\
12 & 49.2 & 29.3 & 10.4 & 43.8 \\
13 & 55.4 & 33.4 & 11.3 & 42.2 \\
14 & 45.8 & 32.8 & 9.5 & 40.7 \\
15 & 55.8 & 31.6 & 10.6 & 43.6 \\
16 & 56.7 & 28.2 & 9.3 & 48.5 \\
17 & 44.7 & 33.7 & 11.2 & 48.9 \\
18 & 47.3 & 30.8 & 12.5 & 40.5 \\
19 & 51.9 & 31.4 & 11.8 & 50.8 \\
Average & 54.5 & 35.3 & 12.1 & 46.4 \\
\hline Standard deviation & $51.3 *$ & 31.8 & 11.6 & 4.9 \\
\hline
\end{tabular}

All the results were compared to control groups with the Kruskal-Wallis test followed by a multiple comparison procedure. *Groups without significant differences among themselves $(\mathrm{p}>0.05)$.

Uzair et al., 2009; Melo-Reis et al., 2010) and are widely used in Brazilian traditional medicine for the treatment of lesions, infectious diseases, and tumors.

The CAM assay is used as an "in vivo" model to study the angiogenic activity of various substances such as growth factors, cytokines, hormones, and transplanted tissues (Zwadlo-Klarwasser et al., 2001). In addition, drug toxicity can be tested with the CAM assay through the assessment of embryonic lethality or deleterious effects to the CAM, including inflammation and neoangiogenesis (Vargas et al., 2007). Compared to other available methods, the CAM assay has advantages such as affordability, and the fact that this procedure does not require ethics approval (Ribatti et al., 1996).

Our results showed that treatment with $10 \mathrm{mg} / \mathrm{mL}$ E. tirucalli latex aqueous solution increased CAM vascular network area. Observations similar to those of our study have been reported in previous studies using other species belonging to the Euphorbiaceae family (Melo-Reis et al., 2010; Mendonça, 2004; Mrué, 2000). Latex from Hevea brasiliensis (rubber tree) increased angiogenic activity and promoted esophagus regeneration in dogs (Mrué, 1997). Further, $H$. brasiliensis latex membrane induced neoangiogenesis in the cornea of rabbits (Mrué, 2000). The same material was used for partial substitution of the pericardium in dogs, and the results showed pericardial regeneration (Sader et al., 2000). In addition, H. brasiliensis latex membrane was used in a myringoplasty and allowed tympanum regeneration (Oliveira et al., 2003).
Latex from plant origin is toxic and consists of a mixture of organic and inorganic compounds, waxy material, proteins, and enzymes, which have important physiological roles (Rajesh et al., 2006), as well as roles in defending the plant against invading microorganisms, insects, and animal predators (Castro et al., 2004). Thus, the pro-angiogenic activity of the latex observed in the CAM assay was probably caused by an inflammatory response because of the latex toxicity, albeit diminished by dilution with distilled water, which led to the migration of neutrophils and macrophages to the site of inflammation (Vargas et al., 2007).

Inflammatory cells are important activators of neoangiogenesis through the production of cytokines, interleukins (IL-1, IL-2, and IL-8), vascular endothelial growth factor, and platelet activator factor. These are cell-specific growth factors that have important roles in the activation and propagation of the inflammatory response, which eventually lead to the growth of pre-existing capillaries and neoangiogenesis in the CAM (Zijlstra et al., 2006).

We analyzed the CAM vascular network in fertilized chicken eggs through the quantification of the percentage of vascularization, histological analysis, and digital imaging. Our results showed that E. tirucalli latex led to the activation of the inflammatory response and formation of new blood vessels, which suggests that $E$. tirucalli latex may have a potential for clinical applications. 


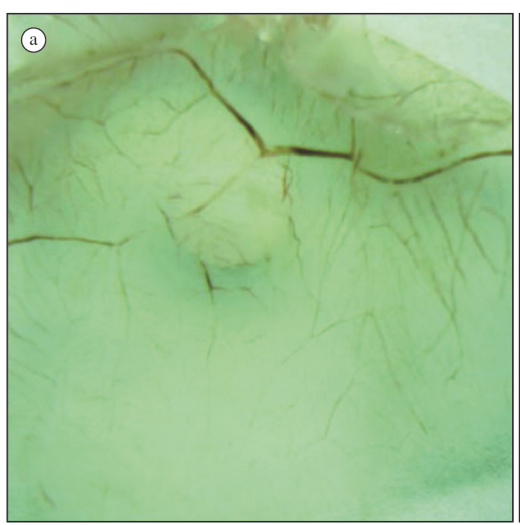

Inhibitor control

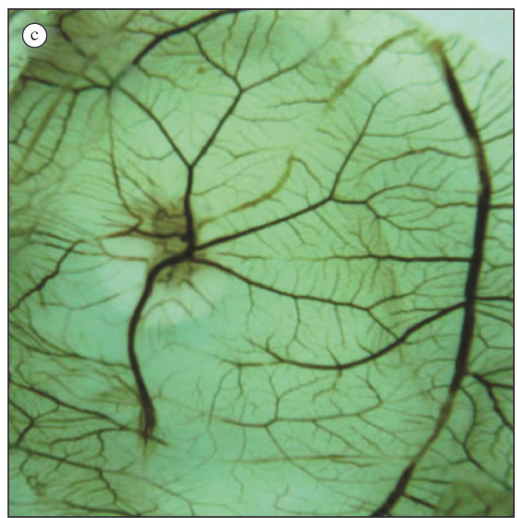

E. tirucalli latex

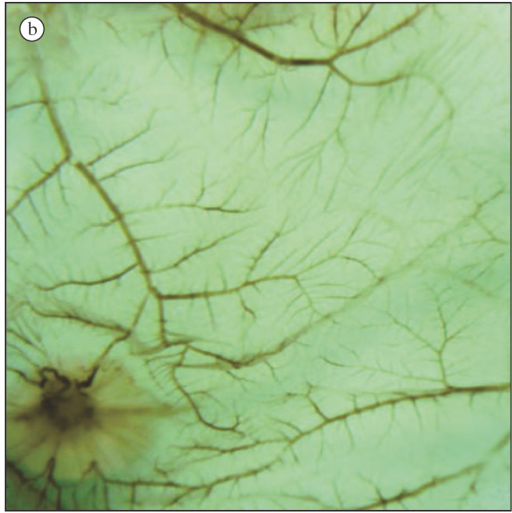

Negative control

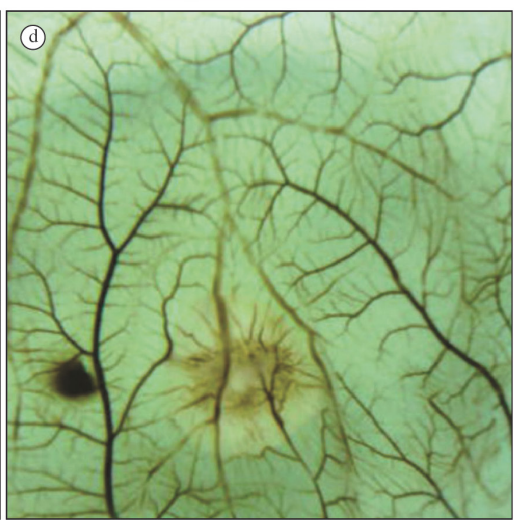

Inductor control

Figure 2. Chorioallantoic membrane (CAM) vascular network formation in the presence of the inhibitor dexamethasone (a); the negative control, water (b); the test solution, Euphorbia tirucalli (c); and the inducer control, Biocure Biomembrane (d).

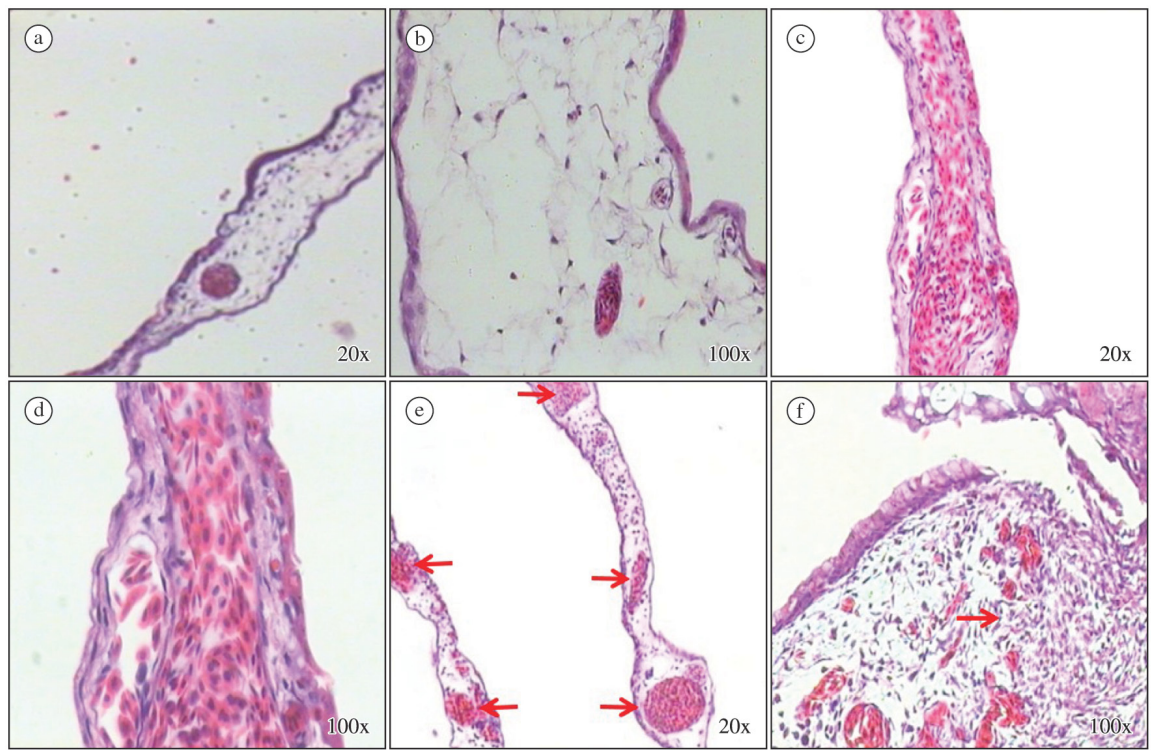

Figure 3. Histological sections stained with hematoxylin-eosin. Chorioallantoic membranes (CAMs) treated with the inhibitor control (dexamethasone) show few connective tissue cells and few blood vessels (a and b). The inducer control (Biocure Biomembrane of Hevea brasiliensis latex) treatment induced a large number of blood vessels and inflammatory foci ( $\mathrm{c}$ and d). Treatment with the test solution of Euphorbia tirucalli latex resulted in a large number of well-organized blood vessels and inflammatory foci (e and $\mathrm{f}$ ). 


\section{References}

AYRES, M., AYRES, JM., AYRES, DL. and SANTOS, AAS., 2007. BioEstat: aplicações estatísticas na área de ciências biomédicas. 4 ed. Belém: Sociedade Civil Mamirauá.

CASTRO, DB., SANTOS, DB., FERREIRA, HD., SANTOS, SC. and CHEN-CHEN, L., 2004. Atividades mutagênica e citotóxica do extrato de Cochiospermum regium Mart. (algodãozinhodo-campo) em camundongos. Revista Brasileira de Plantas Medicinais, vol. 6, no. 3, p. 15-19.

CHOI, S., KIM, KW., CHOI, JS., HAN, ST., PARK, YI., LEE, SK., KIM, JS. and CHUNG, MH., 2002. Angiogenic activity of beta-sitosterol in the ischaemia/reperfusion-damaged brain of Mongolian gerbil. Planta Medica, vol. 68, no. 4, p. 330-335. http://dx.doi.org/10.1055/s-2002-26750. PMid:11988857.

FARNSWORTH, NR., AKERELE, O., BINGEL, AS., SOEJARTO, DD. and GUO, Z., 1985. Medicinal plants in therapy. Bulletin of the World Health Organization, vol. 63, no. 6, p. 965-981. PMid:3879679.

FOLKMAN, J. and INGBER, D., 1992. Inhibition of angiogenesis. Seminars in Cancer Biology, vol. 3, no. 2, p. 89-96. PMid:1378314.

FOLKMAN, J., 1976. The vascularization of tumors. Scientific American, vol. 234, no. 5, p. 58-64, 70-73. http://dx.doi.org/10.1038/ scientificamerican0576-58. PMid:1273568.

FOLKMAN, J., 2004. A novel anti-vascular therapy for cancer. Cancer Biology \& Therapy, vol. 3, no. 3, p. 338-339. http://dx.doi. org/10.4161/cbt.3.3.708. PMid:14726666.

GONZÁLEZ, RP., LEYVA, A., MELO, RAB., MOREIRA, RDM., PESSOA, C., FARIAS, RF. and MORAES, MO., 2000. Método para o estudo in vivo da angiogênese: Indução de neovascularização na córnea de coelho. Acta Cirurgica Brasileira, vol. 15, no. 3, p. 168-173. http://dx.doi.org/10.1590/S0102-86502000000300006.

GURIB-FAKIM, A., 2006. Medicinal plants: traditions of yesterday and drugs of tomorrow. Molecular Aspects of Medicine, vol. 27, no. 1, p. 1-93. http://dx.doi.org/10.1016/j.mam.2005.07.008. PMid:16105678

HEINRICH, M. and GIBBONS, S., 2001. Ethnopharmacology in drug discovery: an analysis of its role and potential contribution. Journal of Pharmacy and Pharmacology, Bethesda, vol. 53, no. 4, p. 425-432. http://dx.doi.org/10.1211/0022357011775712. PMid:11341358.

HUBERT, A. and DE-THÉ, G., 1982. Dietary behavior, way of life, and nasopharyngeal cancer. Bulletin du Cancer, vol. 69, no. 5, p. 476-482. PMid:6299438.

JUÁREZ, CP., MUIÑO, JC., GUGLIELMONE, H., SAMBUELLI, R., ECHENIQUE, JR., HERNÁNDEZ, M. and LUNA, JD., 2000. Experimental retinopathy of prematurity: angiostatic inhibition by nimodipine, ginkgo-biloba, and dipyridamole, and response to different growth factors. European Journal of Ophthalmology, vol. 10, no. 1, p. 51-59. PMid:10744206.

KRUPINSKI, J., STROEMER, P., SLEVIN, M., MARTI, E., KUMAR, P. and RUBIO, F., 2003. Three-dimensional structure and survival of newly formed blood vessels after focal cerebral ischemia. Neuroreport, vol. 14, no. 8, p. 1171-1176. http://dx.doi. org/10.1097/00001756-200306110-00014. PMid:12821803.

KUPCHAN, SM., UCHIDA, I., BRANFMAN, AR., DAILEY JUNIOR, RG. and FEI, BY., 1976. Antileukemic principles isolated from euphorbiaceae plants. Science, vol. 191, no. 4227, p. 571572. http://dx.doi.org/10.1126/science.1251193. PMid:1251193.

MELO-REIS, PR., ANDRADE, LS., SILVA, CB., ARAÚJO, LMM., PEREIRA, MS., MRUE, F. and CHEN-CHEN, L., 2010. Angiogenic activity of Synadenium umbellatum Pax latex. Revista Brasileira de Biologia = Brazilian Journal of Biology, vol. 70, no. 1, p. 189-194. http://dx.doi.org/10.1590/S151969842010000100026 .

MENDONÇA, RJ., 2004. Caracterização biológica de uma fração angiogênica do látex natural da seringueira: Hevea brasiliensis. Ribeirão Preto: Universidade de São Paulo. 85 p. Masters Dissertation.

MRUÉ, F., 1997. Substituição do esôfago cervical por prótese biossintética de látex - estudo experimental em cães. Ribeirão Preto: Universidade de São Paulo. 86 p. Masters Dissertation.

MRUÉ, F., 2000. Neoformação tecidual induzida por biomembrana de látex natural com polilisina: aplicabilidade em neoformação esofágica e da parede abdominal. Estudo experimental em cães. Ribeirão Preto: Universidade de São Paulo. 115 p. Doctoral thesis.

OLIVEIRA, JAA., HYPPOLITO, MA. and COUTINHO NETTO, J., and MRUÉ, F. 2003. Miringoplastia com a utilização de um novo material biossintético. Revista Brasileira de Otorrinolaringologia, vol. 69, no. 5, p. 649-655. http://dx.doi.org/10.1590/S003472992003000500010 .

ORTÊNCIO, WB., 1997. Medicina popular do Centro-Oeste. 2 ed. Brasília: Thesaurus. p. 59.

RAJESH, R., NATARAJU, A., GOWDA, CD., FREY, BM., FREY, FJ. and VISHWANATH, BS., 2006. Purification and characterization of a $34-\mathrm{kDa}$, heat stable glycoprotein from Synadenium grantii latex: action on human fibrinogen and fibrin clot. Biochimie, vol. 88, no. 10, p. 1313-1322. http://dx.doi. org/10.1016/j.biochi.2006.06.007. PMid:16997451.

RIBATTI, D., VACCA, A., RONCALI, L. and DAMMACCO, F., 1996. The chick embryo chorioallantoic membrane as a model for in vivo research on angiogenesis. The International Journal of Developmental Biology, vol. 40, no. 6, p. 1189-1197. PMid:9032025.

SADER, SL., COUTINHO NETTO, J., BARBIERI NETO, J., MAZZETTO, SA., ALVES JUNIOR, P., VANNI, JC. and SADER, AA., 2000. Substituição parcial do pericárdio de cães por membrana de látex natural. Revista Brasileira de Cirurgia Cardiovascular, vol. 15, no. 4, p. 338-344. http://dx.doi.org/10.1590/ S0102-76382000000400008.

SAFATLE, AMV., BARROS, PSM., MALUCELLI, BE. and GUERRA, JL., 2002. Implante de duas membranas biológicas em microbolsa corneana como modelo experimental de angiogênese. Brazilian Journal of Veterinary Research and Animal Science, vol. 39, no. 4, p. 189-195. http://dx.doi.org/10.1590/S141395962002000400005 .

SCHROEDER, G., ROHMER, M., BECK, JP. and ANTON, R., 1980. 7-Oxo-, 7 $\alpha$-hydroxy- and 7 $\beta$-hydroxysterols from Euphorbia fischeriana. Phytochemistry, vol. 19, no. 10, p. 2213-2215. http:// dx.doi.org/10.1016/S0031-9422(00)82230-X.

SLEVIN, M., KRUPINSKI, J., KUMAR, P., GAFFNEY, J. and KUMAR, S., 2005. Gene activation and protein expression following ischaemic stroke: strategies towards neuroprotection. Journal of Cellular and Molecular Medicine, vol. 9, no. 1, p. 85-102. http://dx.doi.org/10.1111/j.1582-4934.2005.tb00339.x. PMid:15784167. 
STATON, CA., STRIBBLING, SM., TAZZYMAN, S., HUGHES, R., BROWN, NJ. and LEWIS, CE., 2004. Current methods for assaying angiogenesis in vitro and in vivo. International Journal of Experimental Pathology, vol. 85, no. 5, p. 233-248. http:// dx.doi.org/10.1111/j.0959-9673.2004.00396.x. PMid:15379956.

UZAIR, M., LOOTHAR, BA. and CHOUDHARY, BA., 2009. Biological screening of Euphorbia helioscopia L. Pakistan Journal of Pharmaceutical Sciences, vol. 22, no. 2, p. 184-186. PMid:19339230.

VARGAS, A., ZEISSER-LABOUÈBE, M., LANGE, N., GURNY, R. and DELIE, F., 2007. The chick embryo and its chorioallantoic membrane (CAM) for the in vivo evaluation of drug delivery systems. Advanced Drug Delivery Reviews, vol. 59, no. 11, p. 1162-1176. http://dx.doi.org/10.1016/j.addr.2007.04.019. PMid:17870202.

WANG, S., ZHENG, Z., WENG, Y., YU, Y., ZHANG, D., FAN, W., DAI, R. and HU, Z., 2004. Angiogenesis and anti-angiogenesis activity of Chinese medicinal herbal extracts. Life Sciences, vol. 74, no. 20, p. 2467-2478. http://dx.doi.org/10.1016/j.lfs.2003.03.005. PMid:15010258.

YAN, SS., LI, Y., WANG, Y., SHEN, SS., GU, Y., WANG, HB., QIN, GW. and YU, Q., 2008. 17-Acetoxyjolkinolide B irreversibly inhibits IkappaB kinase and induces apoptosis of tumor cells. Molecular Cancer Therapeutics, vol. 7, no. 6, p. 1523-1532. http:// dx.doi.org/10.1158/1535-7163.MCT-08-0263. PMid:18566223.

ZHANG, WK., XU, JK., ZHANG, XQ., YAO, XS. and YE, WC., 2008. Chemical constituents with antibacterial activity from Euphorbia sororia. Natural Product Research, vol. 22, no. 4, p. 353-359. http://dx.doi.org/10.1080/14786410701838114. PMid:18322851

ZIJLSTRA, A., SEANDEL, M., KUPRIYANOVA, TA., PARTRIDGE, JJ., MADSEN, MA., HAHN-DANTONA, EA., QUIGLEY, JP. and DERYUGINA, EI., 2006. Proangiogenic role of neutrophillike inflammatory heterophils during neovascularization induced by growth factors and human tumor cells. Blood, vol. 107, no. 1, p. 317-327. http://dx.doi.org/10.1182/blood-2005-04-1458. PMid:16174763.

ZWADLO-KLARWASSER, G., GÖRLITZ, K., HAFEMANN, B., KLEE, D. and KLOSTERHALFEN, B., 2001. The chorioallantoic membrane of the chick embryo as a simple model for the study of the angiogenic and inflammatory response to biomaterials. Journal of Materials Science: Materials in Medicine, vol. 12, no. 3, p. 195-199. http://dx.doi.org/10.1023/A:1008950713001. PMid:15348302. 